\title{
11. Re-imagining the Australian state: political structures and policy strategies
}

\author{
Ian Marsh
}

\begin{abstract}
Can the State reasonably pursue the task of nation-building if governments are not prepared to adapt the machinery of State in step with the evolving nature of society and emerging challenges? Australia's present political system was conceived in, and designed for, the very different social conditions that existed in the early nineteenth century. At that time, the two major parties broadly articulated a real social divide and developed organisational machinery that effectively mobilised the surrounding society: that provided opportunities for debate of emerging issues, engaging activists and providing cues to their followers about how to judge issues. Now the social base of the political system has been transfigured. Domestically, the community is pluralised and differentiated, class identity has decomposed and variety of new issues has undermined both the older collectivist identities and the autonomy of domestic politics. Consequently, the public agenda has expanded, differentiated and become more complex. Over this same period, the party organisational machinery that formerly mediated citizen and activist mobilisation and engagement has been jettisoned. No compensating machinery has been developed. As a result, the public conversation about major emerging issues languishes. How, then, can governments hope to chart a path for nation-building? What institutions will we require to support a truly 'national' dialogue about the meaning of 'nation' and the kind of society we're trying to create? I argue that a reconfigured Parliament might engage citizens and interest groups in 'government by discussion'. For that to occur public disaffection will doubtless need to attain new heights, and new political entrepreneurs will be needed to champion the message that there is another way.
\end{abstract}

\section{Introduction}

Building a nation requires the establishment of civil and legal institutions as well as a political culture within which some sort of collective vision of national destiny might be forged. These are the essential prerequisites for nation-building as they provide both the forum and the instruments for the articulation of public policy and the pursuit of policy goals through implementation. In this chapter, I examine those features of Australia's political culture and institutions that diminish deliberative processes and thereby compromise the capacity of the Australian polity to collectively determine any future nation-building agenda. 
Australia's present political system was formed in the early twentieth century. The formal structure emerged roughly from 1909 when Free Trade and Protectionist parliamentary groups merged. The architecture of executive-administrative power that was then constituted persists to this day. At its establishment, this architecture reflected prevailing political narratives and social cleavages. Socio-economic class was then the dominant political fault-line. Socialism and social liberalism were the dominant narratives. Present Australian cleavages and narratives bear little relation to those of the early twentieth century. Australian society is more differentiated at every level: ethnically, economically and in citizen aspirations. Socio-economic class has ceased to be the only, or indeed - depending on the issue - the primary, determinant of political orientation. There are no comprehensive political narratives. Think of alignments on WorkChoices, climate change, indigenous reconciliation, refugees, same sex marriage, education and a host of other issues. The first theme of this chapter concerns the need to better align the formal structure of politics to a more pluralised social base. The formal system no longer sufficiently engages this base in the national conversation about policy choices and options. But how might this outcome be achieved? What form might an amended structure take?

A second theme concerns the likelihood of change actually happening. Several scenarios can be imagined. Some involve a turn away from the major parties on the part of electors. But another scenario, albeit perhaps more remote, involves action by political elites themselves. They might yet come to see moves down this path as being in their own political interest. The seven policy U-turns of the Howard government from early 2007 provide powerful evidence of the profound gap between the present formal system and the surrounding society. This gap is a threat to any government with an ambitious policy agenda.

The discussion proceeds as follows. The first section discusses the importance of an informed public from the specific perspective of the policy choices that are available to the executive. It also discusses recent changes in the dynamics of opinion formation. This summarises and extends arguments that I have developed at greater length elsewhere $(1985,1995,2006,2007$, Marsh and Yencken, 2004). A second section reviews three underlying symptoms of 'dysfunctionality' in the present formal policy-making structure. Drawing on Australia's experience pre-1909, the third section discusses the possible form of an amended system. The formal structure of policy-making would be augmented by what Michael Keating has termed a 'contemplative phase'. In this phase two key tasks would be initiated: on an analytic plane, the issue would be introduced to the public agenda and its broad scope defined; in parallel, on a political plane, the engagement and mobilisation of interests would commence. Neither of these tasks is routinely part of existing processes. A concluding section briefly reviews some scenarios that might be associated with such structural change. 


\section{The changing dynamics of opinion formation}

Public opinion underwrites executive choices and action. While they must sometimes confront their publics, political leaders mostly need to work with the grain of public opinion. Public opinion plays a role in the political system roughly analogous to that of money in the market system. It is the unit of exchange. But opinion does not spring into life spontaneously or ready formed. Rather, public opinion develops reciprocally in the context of issues, institutions and, perhaps most importantly, ideas. It develops like a snowball. It starts in the belief of a few people that action is required on a particular issue. The protagonists could be community activists, business leaders, university experts, ministers or MPs. Through persuasion and argument the number of people who share a concern progressively expands. If this does not occur the issue dies. But if a concern is to grow in significance, more organised actors need to become involved. This can happen as particular individuals or groups give cues to others or as coalitions take shape (e.g. Yankelovich, 1992; Zaller, 1992).

There are numerous practical examples of these abstract propositions. Take the literature on the rise of the social movements (e.g. McAdam, McCarty and Zald, 1996; Braithwaite and Drahos, 2000) or the emergence of neo-liberal politics in the US and Sweden (Blyth, 2002). Or consider the impact of the abortion debate in the Australian Parliament (Hansard, 9 February 2006), or the Get-Up campaign on behalf of David Hicks. ${ }^{1}$ Perhaps the most recent vivid example, yet to be fully documented, concerns the development of public opinion on climate change to which protracted drought, Al Gore's film 'An Inconvenient Truth' and the Stern Report presumably all made major contributions.

In any polity, the formal political system is the principal stage for this process. It constitutes a kind of artificial theatre. Its succeeding acts and scenes and its cameo dramas can be the settings from which, and through which, views are transmitted from one group to another. By these means, public attention is mobilised. The distinctive role of Parliament is apparent in the fundamental split between this setting and the administration. Cabinet and ministers provide the link. They are the only actors with standing in both sub-systems. Meanwhile, political exchanges occur mostly in and around parliamentary rituals or parliamentary settings. Question Time, confidence motions, urgency motions, ministerial statements, legislation and (to a lesser degree) committee hearings are the settings in which agendas are established and through which arguments are developed and priorities communicated. These settings provide raw material for the daily media.

Bernard Crick once described parliamentary rituals as tantamount to a continuing election campaign. Reflecting this spirit, they are almost wholly adversarial in character. But in the process of regulating the struggle for power in a developed and civilised democracy, these processes are also supposed to foster social 
learning. Indeed this is their ultimate rationale. In democratic theory, as the political conversation unfolds, the public becomes better informed (e.g. March and Olsen, 1995; Pettit, 1997; Dryzek, 2000). Public opinion should be refined and distilled as more views are accommodated, more questions answered, more uncertainties dispelled and more consequences recognised. This is the path to effective and adaptive governance.

The premise that social learning is best fostered through adversarial rituals involves a number of assumptions. First, it assumes that there is a fundamental programmatic difference between the major parties. This was indeed broadly the case when the Labor Party was formed. It could be plausibly argued that this persisted until roughly the early 1970s, when both major parties adopted a catch-all stance (e.g. Mair, 1997; Marsh, 2006b). This marked the beginning of convergence on policy between the major parties, a process that is now virtually complete (e.g. Blyth and Katz, 2005). Second, adversarialism assumed that party difference derives from underlying normative orientations that are reflected in whole agendas and programs. Debate does not need to focus on particular issues or on the detail of proposed measures because measures and instruments are assumed to be almost wholly implicit in the competing party programs. We will want to revisit the continuing relevance of these basic assumptions.

In recent decades, the media have come to play increasingly critical transmission and brokerage roles between the formal system and the citizens that it (ostensibly) serves. Media roles have waxed as those of other political institutions (notably the major party organisations) have waned. The media often determine which issues and which voices will be given prominence. However, they rarely set the agenda. This usually involves either top-down announcements by the political leadership or sustained bottom-up campaigning (e.g. Get-Up and David Hicks). The media mostly disseminate or re-package messages that others have originated. Key commentators transmit opinions and influence the views of others. They can be very important cue givers. But the media rarely determine the options that enter public debate.

In step with the rise of the media, there have been other changes in the approach of party leaders to informing and influencing public opinion. Perhaps unintentionally, they have largely turned from leading to following the community. With some qualifications (noted in a moment), party leaders now often take their cues from focus groups or talkback radio. This outcome is a consequence of developments from the 1970s. Around that time, the major parties changed their approach to the development of public opinion. The appointment of a new style of party manager was symptomatic of this change. Professionals in public opinion polling and marketing replaced party loyalists (e.g. Mills, 1986). They promised a new outcome. Direct marketing, polling, media 
advertising and packaging promised to render dispensable organisational policy development and a large party membership base. Clever marketing, focused on the parliamentary leadership, could, it was imagined, sufficiently compensate for weakened party identifications among electors. Indeed conferences, large memberships and internal policy development processes came to be seen as constraints on the political leadership. Liberation from them allowed the parliamentary leadership to reach out directly to the electorate. Sophisticated marketing techniques seemed capable of delivering the required outcomes in mass opinion formation.

A direct approach to the electorate via the media is clearly one viable option for building public opinion but there are many constraints. Media requirements for a punchy 'grab' distort presentations. The media have difficulty maintaining attention on an issue without sensationalising developments. The media have commercial interests, which are not necessarily consistent with the development of an informed public opinion. In sum, media requirements for a punchy grab and their short attention spans have, arguably, significantly diminished public understanding of policy issues and choices (e.g. Lloyd, 2004 ; Henry, 2007). In addition, the focus of public debate on party leaders limits the development of an informed public opinion in fundamental ways. Most major policy announcements are made by the Leaders of the major parties. This means that the leader's prestige is implicated in the successful implementation of whatever has been proposed. A focus on the party Leaders foreshortens the time available for reciprocal exchanges between protagonists and limits the scope for developing public and interest group opinion. It also turns many issues into futile jousts between governments and Oppositions.

Further, market practices are now in common use for policy development: increasing attention is given to focus-group and opinion surveys by ministers, departments and political parties. A reliance on focus groups and talk back radio means knee-jerk public responses and unformed opinion are given inappropriate standing. Finally, policy has been merchandised by the use of commercial advertising to project messages to the general public. Look no further than the recent campaigns associated with WorkChoices, domestic violence or the tax system. Fred Argy has estimated the Howard governments together spent some two billion dollars on advertising and policy promotion - an astonishing sum (Argy, 2007). These developments deflect attention from actions that might be taken to develop better-defined strategies and public opinion about them. There is limited scope for actions that might refine and deepen public opinion and, hence, limited attention to such possibilities.

\section{Three symptoms of a corrupted policy-making system}

There are at least three symptoms of a policy-making system that has become corrupted in its capacity to build an informed public opinion. These are public 
views about the system, contemporary representational patterns and the experience of the Howard governments.

\section{Public trust and confidence}

What does the public think about the system? There is an extensive international literature which includes data on Australia that documents the decline in citizen trust (e.g. Dalton, 2004; Stoker, 2006). Recent data also shows that Australians maintain high levels of 'satisfaction with the democracy' with Australian results only second to those of Denmark (McAlister, 2007). Of course it is unclear whether this reflects an underlying faith in government, (for example a primarily normative orientation broadly consistent with a utilitarian political culture) or a judgment about the current structure. I have always been attracted by Peter Bowers (thoroughly utilitarian) reading of our national psyche: 'There is an ephemeral timelessness about the desire of Australians for the ideal party that will govern Australia fairly and wisely for all Australians. Australian politics are driven by a perverse romanticism that few Australians are willing to admit because it runs counter to the preferred national persona of treating all things political with an arid cynicism better suited to a race that has lived in a hard dry country for two hundred years' (Sydney Morning Herald, 10 March 1990). In the same spirit perhaps, Greg Craven is credited with proposing that Australians are radical about only one thing: that their politicians be moderate (cited by Ross Gittins, Sydney Morning Herald, 28 November 2007, p. 15).

When it comes to politicians, public distrust and cynicism is plain. Federal members of Parliament rank twenty-first and State members twenty-second on the Morgan list of 29 professions as ranked by trustworthiness. Split ticket voting is an indicator of caution amongst electors. While the numbers fluctuate, in recent years up to $25 \%$ of the electorate has voted for different parties in the Senate and the House of Representatives. In other words, many Australians like divided government. Further, political parties are themselves increasingly unpopular. In 2001, $76 \%$ of Australians indicated they did not think parties care about what people think and in 2004, 70\%. In 1993 only 56\% held this view. In 1998, 67\% of respondents indicated that they think that people in government look after themselves. In 2001 this increased to $68 \%$ but declined to $61 \%$ in 2004 . Similarly, in $1998,82 \%$ said government was run for a few big groups. This declined to $74 \%$ in 2001 and $67 \%$ in 2004 .

The collapse of visceral voter loyalty to one or other of the major parties is also evident. Between 1967 and 1997, the number of Australians without a party identification increased from roughly two percent to around $17 \%$. Further, the number acknowledging only weak identification has increased from $23 \%$ in 1967 to around $36 \%$ in 1996, 34\% in 2001 and 32\% in 2004. Thus, between 50 and $60 \%$ of the electorate have no - or only weak - identification with one or other of the major parties. High levels of party identification were formerly 
regarded as the sheet anchor of the Australian political system (e.g. Aitkin, 1977). The erosion in party identification has also diminished the symbolic power of party names. The collapse of party identification means the party 'brand' is no longer sufficient by itself to evoke a loyal response from most voters. This is a particularly significant trend if party names are relied on as a primary cue for citizen attitudes.

\section{Representational patterns}

A deeper symptom of misalignment between the formal system and the surrounding community is associated with representational patterns. The formal political system is based on two major parties. For many years these two parties effectively reflected a social reality. Some locate the sources of citizen party identifications in economic circumstances (e.g. Gollan, 1960) and some in cultural and religious orientations (e.g. Brett, 2003). Whatever its source, the notion that a broad cleavage divided Australian society and that this was reflected in the two major parties was widely accepted. As I have argued elsewhere, the contemporary diversity of Australian society, reflected in the proliferation of interest groups and social movements, is arguably the single most important change in the character of post war domestic politics (Marsh 1995, Chapter 2).

Nine major social movements emerged in the 1970s. These championed the environment and rights for women, gays, indigenous Australians, consumers, ethnic Australians and animals. They promoted peace and third world issues. Finally, advocates for the 'new right' have also exerted a powerful influence on political, business and media elites. This has been based on think tanks rather than mass mobilisation. They have generally championed atomised individuals as the only salient political unit.

These diverse groups variously encouraged the formation of other groups, whether in imitation (e.g. the republican movement) or to defend the status quo (anti-abortion movement; monarchists) or to further liberalise the policy agenda (e.g. euthanasia, drugs). Together these developments signify a new diversity in citizen identities (e.g. gender, ethnicity, environmentalism). They mostly augment, and sometimes displace, older class-based cleavages. A linear, left-right continuum was once an apt image of the electoral spectrum. In contemporary Australian society, a kaleidoscope seems a more apt metaphor. This image conveys the diversity and fluidity of political attachments that now characterises the Australian community.

Indeed, it is hard to overstate the degree to which Australia has become a group-based community. The array of organised actors on any issue is legion. These groups vary enormously in size, budgets, political skills, organisational sophistication and campaigning capacities. But the major ones are as effectively organised as the major political parties. 
As a consequence, activists no longer have strong allegiance to one or other party and the way that issues are introduced onto the national stage has shifted. It has largely ceased to be an internal process dominated by major party organisations. Party forums are not the principal arenas for activists. Internal processes do not provide the medium for testing the acceptability of proposals or for seeding opinion formation. The initiative has moved elsewhere. Public opinion has been influenced through public campaigns by activists and through the resultant media attention. This has been used to pressure the parliamentary leadership of the major parties to adopt new agendas. The success of these campaigns has significantly widened the national political debate and raised the importance of public opinion formation.

The emergence of an array of interest groups and social movements in the post-1960s period is important because these organisations are durable. They both represent and sustain particular interests and positions - and they seek to persuade the undecided. The space between the major parties and the community is now filled by organisations with political nous and media skills and with a demonstrated capacity to shape opinion on particular issues.

Some commentators have decried or downplayed this development. They have claimed there is a mute but underlying 'silent majority'. Or they claim a minority has established a code of 'political correctness' that has staunched the expression of dissent. Or they claim public debate has been taken over by a 'new class' of self-interested individuals in the pay of the state. But the image of the Australian community as a vast silent majority with a noisy fringe of pressure groups is wrong. Talk of a 'new class' as some alien sectional minority who have subverted the public interest in favour of their selfish and unrepresentative concern is wrong. The idea that Australian society has been taken over by a politically correct discourse to the exclusion of a more authentic and unified Australian voice is wrong.

These images may be useful rhetorical ploys in the political game but they do not reflect reality. The pluralisation of Australian society is the fundamental fact - and unless political leaders can persuade us to jettison some of our varied aspirations, it is here to stay. It is evident in values and social attitudes, between regions and community groupings and at the level of organised political action.

Yet these groups lack access to the formal policy-making system. There is no institutional machinery that allows the system to routinely reach out to groups and assess their views. Further, on any issue some will be opposed (the immediate 'losers'), some will gain and others will be undecided depending on how the issue is framed. The formal system lacks routine capacities to bring these last two groups into the consultative process, to create space for redefining the issue, for initiating the formation of coalitions and for engaging in other actions that 
might better integrate the social base and the formal policy-making system. Let us explore some of the consequences.

\section{The policy-making structure in practice}

To understand the way the policy-making system actually works, recall some of its formal premises. One fundamental premise concerns the role of elections. These are assumed to deliver an unqualified mandate to the winning party. The doctrine of ministerial responsibility and the architecture of political-bureaucratic relations derive from this premise. The political authority gathered through an election victory is generally assumed to be sufficient to underwrite executive decision-making. This is also the premise behind Bernard Crick's description of the adversarial political system as tantamount to a continuing election campaign. Of course, in practice, this is less than absolute. For example, many years ago Robert McKenzie described the actual role of interest groups in words that continue to be relevant:

I have suggested that any explanation of the democratic process, which ignores the role of organised interests, is grossly misleading. I would add that it is hopelessly inadequate and sterile in that it leaves out of account the principal channels through which the mass of the citizenry brings influence to bear on the decision-makers whom they have elected. In practice, in every democratic society, the voters undertake to do far more than select their elected representatives; they also insist on their right to advise, cajole and warn them regarding the policies they should adopt. This they do for the most part, through the pressure group system (1958, p. 9).

Indeed, as discussed in the previous section, interests have multiplied in recent years, far beyond their incidence when these words were penned. In the process, they have fractured the former almost absolute mobilising role of the major parties. However, assumptions about executive authority have not assimilated this development. They remain unchanged as the examples we will shortly review attest. In brief, the incentive structure in the formal system implies that any need to build power for a particular decision can be sufficiently handled by a prime minister or individual ministers on an ad hoc basis (e.g. gun control, GST). ${ }^{2}$ There is no need for an additional phase in the policy system that would oblige ministers to routinely engage with affected interests before final decisions are taken by Cabinet. There is no need for a phase that would routinely engage the broader public without committing the government's prestige. There is no need for the addition of a routine process that would allow governments to trial arguments and evidence and gain intelligence about community and interest group views. There is no need for a phase where processes of coalition-building 
might be initiated. There is no need for what Michael Keating has elsewhere described as a contemplative phase (Keating, 2004, p. 154).

How does the experience of the Howard government illuminate this need? Its defeat challenges a variety of assumptions about the way the system works. One concerns the relationship between policy-making and political strategies. Prime Minister Howard gained a reputation for his tactical cunning and shrewdness. Surely victory in four election campaigns attests to high political skills? But these victories were often based on populist tactics and opportunism or on the spending that good times allowed. Only one election was fought on a contested policy agenda - that involving the GST in 1998. All the others substantially included 'wedge' or 'dog whistle' tactics and played on populist themes, most egregiously in the case of the Tampa episode. Howard was also adept at exploiting leadership weaknesses in his opponents.

Some may wish that politics could occupy a more elevated plane but in the context of a convergence in agendas between the major parties, a populist turn seems inevitable (e.g. Mair, 2002; Marquand, 2004). In this context, the 2007 election is of especial interest. The accession of Kevin Rudd to the Labor leadership in December 2006 was followed by an immediate lift in Opposition standing in the opinion polls. Further, Rudd adopted a very low political profile - carefully avoiding potential wedge issues. Thus many of the tactics that Howard had used so successfully against his earlier opponents were unavailable. And fortune delivered no fresh wedge opportunities.

So policy came into focus. Here the Howard government was forced to acknowledge the considerable gap between the positions that it had championed and public opinion. From late 2006, it backtracked on not one or two but on at least seven quite fundamental issues: education, management of the Murray Darling basin, indigenous reconciliation, refugees, broadband, WorkChoices, and climate change. Of course prime ministers must always be ready to trim for an election. But this represented a wholesale repudiation of announced past positions and attitudes across a wide and fundamental range of issues. This was an unambiguous example of politics driving policy. But what did these U-turns say for the government's previously stated views? Were they wrong? And what is the public to think? Are political leaders' complete chameleons or hypocrites? Do the merits of issues have nothing to do with their determination?

It is instructive to revisit the policy development processes that had been associated with these issues. WorkChoices is the most notable example. This issue was not discussed in the 2004 campaign. Shortly after his election victory, Howard set his department to work canvassing options for change. These were discussed in Cabinet. We now know that there was a considerable divergence amongst ministers about the severity of the measures (The Australian, 27/11/2007, p 7). The Workplace Relations Amendment (WorkChoices) Bill 2005 was 
introduced to the House of Representatives on 2 November, 2005. It was a complex piece of legislation amounting to 762 pages. It went to the Senate on 10 November and was finally passed on 2 December. In sum, 11 days of parliamentary time (House six and Senate five) had been devoted to debate and most of this was grandstanding rather than detailed discussion. At no point were affected interests - business, contractors, trade unions for example - drawn into the conversation. The government lacked a basic understanding of interest group and community views. Interests and the broader community were not engaged in a conversation about needs and options. There was no contemplative phase. There was, rather, only private deliberation and public announcement. Thereafter the policy was 'merchandised' to the electorate through a \$55 million advertising campaign (Argy, 2007). The union movement responded with its effective Your Rights at Work' campaign. Notably, this was based on sustained grass roots mobilisation as well as advertisements (Sydney Morning Herald, 17-18/11/2007, p30). This forced the government to change ministers (Hockey replaced Andrews in late January 2007) and culminated in a major policy U-turn early in 2007. The former policy was effectively gutted (Wooden, 2007). A further \$61 million advertising campaign was launched to merchandise the new approach. Would earlier disclosure of intent and options have produced a different outcome? Of course, the government might have thought such disclosure would have provided ammunition to its opponents. No doubt it also assumed that its right of decision was licensed by the 2004 election. In the event this proved to be a false assumption, with (from its perspective) disastrous consequences.

The other examples of policy U-turns involve issues that were perhaps not so profoundly damaging politically. But they do involve policy development processes that parallel those we have just reviewed. Take indigenous affairs. The government's intervention in the Northern Territory in July 2007 involved land rights and the permit system for communities as well as domestic violence, access to alcohol and sexual abuse. But these measures were introduced with no advance consultation with indigenous leaders and without the preparation of broader public opinion. Yet, as far back as 1999 a report entitled Violence in Indigenous Communities had been prepared for the Department by Dr Paul Memmott. This was not released by the then minister (Vanstone) until 2001. The government did not seek to seed a wider discussion about policy options. Meanwhile, ATSIC had been addressing these questions, although how effectively is unclear. In the event, ATSIC's funding was cut by $\$ 460$ million in the first Howard budget. Thereafter funding was progressively cut until its abolition was announced in April 2004. Prime Minister Howard's position on indigenous issues was publicly clear. He condemned the so-called 'black arm band' view of indigenous history in Parliament on October 30, 1996, and again in the Sir Robert Menzies Lecture, which he delivered on 18 November of the same year. On May 
26, 1997, Prime Minister Howard repeated this argument at the Reconciliation Convention marking the thirtieth anniversary of the referendum. This theme continued to dominate his public remarks until his adoption of the new narrative of practical reconciliation in March 2000 (Sydney Morning Herald, 30 March 2000).

In 2003, the indigenous leader Mick Dodson spoke forcefully at the National Press Club about violence, alcoholism and sexual abuse (Sydney Morning Herald, 30 June 2007, p. 35). Nothing happened. An inter-governmental summit on violence and child abuse was held in 2006. This pointed to the cost and blame shifting that characterised federal-territory and state relations. Nothing happened again. There had thus been discussion of the problem of alcohol and sexual abuse at a technical level for at least eight years. The Little Children are Sacred report supervened. It was tabled in the Northern Territory legislature in June 2007. The federal government's response was announced in August 2007 as a national emergency, three months prior to the election. Whilst firm evidence is unavailable, it is hard to believe there would not have been some community scepticism about the government's motives.

Climate change reflects a similar pattern of announcements without any prior contemplative phase. Two key events here involved the government's response to the Kyoto decision and the publication of an energy White Paper in 2004. The preparation of this document commenced in 2003 and followed the familiar pattern. The government called for submissions and attracted 33 responses. These were considered in private - then a report went to Cabinet and the White Paper was announced in Parliament on 15 June 2004. On this occasion there was a parliamentary committee hearing which had no apparent influence. But we know from other accounts that industry representatives enjoyed privileged access to the policy-making process and met with ministers in private (Pearse, 2005, cited in Hamilton, 2007). The government's position was projected through ministerial statements and policy announcements.

Meanwhile, the States had progressively moved to develop emissions trading schemes. Perhaps responding to the Stern Report and An Inconvenient Truth and the change in public mood that they seemingly stimulated, Prime Minister Howard appointed a Task Force on 30 November 2006 to look at a national scheme. This group took submissions in private from affected interests. Its conclusions provided the basis for a Cabinet submission. This was considered in mid 2007 and the government decision endorsing a scheme (but postponing any decision about targets) was announced in June 2007 (Sydney Morning Herald, 5 June 2007). In September 2007, with an election campaign pending this decision was reversed. At the same time the pronouncement against mandatory renewable energy targets in the 2004 White Paper, Securing Australia's Energy Future, was also reversed. Again, the government seemingly lacked early intelligence about 
the development of public opinion and lacked any detailed capacity to communicate its views to a wider public during its earlier years in office.

Two other illustrations of broadly similar policy development processes are provided by policy announcements on the Murray Darling Basin and education. In relation to the Murray Darling Basin this policy issue first entered the agenda around 1992 when the Murray-Darling Basin Agreement was established. Implementation was in the hands of the Murray Darling Basin Commission. Not surprisingly, this 25 member body proved incapable of coming to grips with the issue. It was subsequently joined by a host of special purpose authorities: Riverbank, the National Water Commission, Water for Rivers, catchments management authorities, The Living Murray. At least two other programs were announced: the Achieving Sustainable Groundwater Entitlement program and the National Water Initiative. Another consultative round between the Commonwealth and the States occurred in 2002. According to Ross Gittins, National Party pressure meant one key option was never considered - that is allowing city buyers into the market for Murray water (Sydney Morning Herald, 30 May 2007). Another issue that was proved too politically contentious was the over-allocation of water rights by New South Wales compared to the under-allocation by Victoria. It is worth noting no official enquiry ever directly addressed these issues and no distinctively political enquiry mechanism existed for addressing the federal-state and state-state issues in a sustained way. Grandstanding between the States and the Commonwealth dominated the public conversation.

Education is the only policy area that slightly qualifies the above picture. The government cut funding in its first budget in 1996. In January 1997 it established the West Review. This was a standard approach to policy investigation. Consultations amounted to soliciting the views of affected interests. The enquiry reported. The department and the Cabinet decided. The resulting ministerial statement was a squib. In the second Howard government, Minister Kemp sought to introduce a voucher like system in higher education. But his Cabinet submission was leaked in 1999 and the idea never got off the ground. Note Kemp's approach. He assumed the right way to introduce a radical initiative was to take a paper to Cabinet and if successful announce a change. This conforms to the formal norms of the system. But no part of that process involved the engagement of public and interest group opinion. Yet how could such a change be contemplated without intelligence about reactions and about the compromises that might have been necessary to gain support for the proposal. In the third Howard government, Minister Nelson went some way down this path in the consultations he lead in the development of the review Higher Education at the Crossroads. In April 2002 a discussion paper was released. It attracted 355 responses. Between June and September six papers on key issues were released. This elicited a further 373 submissions. Nelson also held directly or commissioned 
48 forums covering all States. The government's response was announced 13 May 2003 as part of the Budget. Thereafter Nelson engaged the Democrats and modified some proposals to ensure their support. This exercise moved policy development closer to the 'contemplative phase' envisaged by Keating. But it involved the minister directly. It was a very time consuming process. The results of the review were not publicly available for comment before final decisions were taken and there was barely any reach beyond immediate stakeholders into broader public views.

The foregoing examples illustrate the very deep failings in present policy-making arrangements. There were failings of intelligence, communication and mobilisation. These were not the result of lapses by individual ministers. They reflect the false assumptions about political authority that are embedded in current policy-making processes. They reflect the enhanced political power of organised interests and the absence of effective integrating infrastructure. Effective in this context refers to the ability to develop and/or accommodate views, to construct coalitions and, if necessary jettison, adapt or build institutions. They also reflect the acute limitations of the media as a primary link between the government and the broader community.

Of course in the recent past public understanding of government policy stances has mostly not been a primary factor in political strategies or campaigns. Tacit bipartisanship has been an important, albeit top-down, driver of policy change. But general public perceptions of competence in relation to the economy and national security have been primary. Wedge tactics, populism and leadership appeal have also featured prominently. But when these ephemera were unavailable policy issues came into focus. When this occurred, the dysfunctional character of present policy-making arrangements can be clearly seen.

\section{An augmented system?}

How might a contemplative phase be introduced to the present policy-making structure? For guidance we might turn to the political architecture that characterised the first decade of the twentieth century. Between 1901 and 1909 three parties, Protectionist, Free Traders and Labor, competed for public support. No party won an outright parliamentary majority. Elections produced a Parliament composed of members whose aspirations and attitudes diverged widely. Without a majority party in Parliament, governments were created and unmade according to their ability to gather majority support for their programs and for particular measures. They were also required to obtain majorities in two chambers. This brought into focus the political mechanisms available for building backbench and inter-house support both for governments and for individual measures. 
This more fluid political context required a contemplative phase in the policy-making process. This involved parliamentary capacity for an initial assessment of strategic issues. This offers perhaps the most vivid contrast between the pattern of policy-making in the two-party period, and that in the more plural political world that preceded it. In the two-party period, the primary task of strategic political inquiry has been intellectual 'expert' investigation of a complex new issue to recommend what should be done. Examples are the Campbell Report on financial deregulation, or the McClure Report on the welfare system or the Hogan Report on nursing home financing. The government, having established these inquiries, assumed its prior electoral victory gave it sufficient authority to implement the findings, should it agree with them.

The situation was different in the more plural world of 1901 to 1909. The diversity of the Australian community was then mirrored in the existence of three parties. Contested strategic issues were introduced in Parliament before the parties had announced their firm policy stances. This allowed a process of intellectual analysis, political and public exchange and learning. Through this process, political authority sufficient to permit their resolution was mobilised. Indeed, the two tasks of refining analysis and mobilising consent overlapped. Parliamentary inquiries represented a key step. We can see this in operation in the parliamentary enquiries that occurred. Over this nine-year period, 17 select committees and royal commissions were established. MPs dominated most of these inquiries. Fourteen of the 17 inquiries began as parliamentary select committees and were later converted to royal commissions. This was only because the life of a select committee was limited to the parliamentary session in which it was established.

Of the 14 parliamentary inquiries, eleven offer the remarkable spectacle of MPs engaged on major strategic investigations that went to the heart of policy-making and administration. The first major category of enquiries involved those concerned with the strategic agenda. Enquiries occurred at key stages from the point that an issue emerged on the political agenda to the determination of legislation. Seven of the eleven inquiries concerned issues at the frontier of the political agenda: the tariff, the desirability of nationalisation of the tobacco cartel, the need for Australian control of shipping services, federal old age pensions, access to press cable services, Papua, and the future of 'New Protection' following the High Court rejection of the arrangement proposed in 1907.

By far the most significant inquiry in scale, duration and impact was that into the tariff. This was first suggested by the radical Protectionist, Sir Isaac Isaacs, in October 1904 and was established by the Free Trade Prime Minister George Reid in December 1904. The group of eight MPs consisted of three Free Traders, three Protectionists and two Labor members, with two representatives each from New South Wales and Victoria and one from each other state. The inquiry 
commenced in 1905 and concluded in the middle of 1907. At the outset, it surveyed virtually all significant Australian manufacturers and importers to identify tariff anomalies, local capacity, cost obstacles, special factors and so forth. This covered 2801 establishments. Evidence was gathered over the two years 1905 and 1906. The inquiry held sittings in all capital cities and major provincial centres. In total 211 sittings were held and 618 witnesses examined. Over 3,000 pages of oral evidence were printed. The oral and written evidence offers a unique and comprehensive account of Australian industrial capacity and of the barriers and vicissitudes to which it was subject on account of the scale of domestic markets and the vigour of international competition. The Commission produced 46 individual reports on the various tariff heads. The significance of this inquiry lies not so much in the findings, perhaps predictable given the rival ideologies, but in the immense research, outreach and mobilisation effort that the inquiry represented.

Contested legislation was the second major area of strategic policy-making to which parliamentary inquiries made a particular contribution. The Bonus for Manufactures Bill 1904 was a Protectionist initiative resisted by a strong faction of their erstwhile Labor supporters on the grounds that local iron production would prohibitively boost upstream costs. By contrast, the Navigation Bill 1906, sponsored by the Reid-McLean government stumbled on Labor insistence on Australian crews and special conditions for coastal trade. These were both extensive inquiries that produced divided reports. Neither issue was finally resolved before 1909. Parliamentary inquiries as a vehicle for investigating contested legislation represented a role for Parliament and MPs that has only recently been revived (e.g. GST inquiries).

Finally, two inquiries involved oversight of major government activities: review of electoral administration in 1904 and the Post Office review in 1908-1909. The Post Office review was almost on the scale of the tariff inquiry. It involved a comprehensive assessment of this key federal agency. A minority (Labor) report opposed the restriction of female occupations to typing, telegraphy and monitoring!

To discount these inquiries because their recommendations were not wholly bipartisan or not accepted by the government is to misperceive the role and contribution of parliamentary inquiries in a pluralised political environment. In this more fluid political context, parliamentarians played much more prominent roles in agenda setting and issue refinement. ${ }^{3}$ Their judgements were critical to advance of these issues through the policy development process. Parliamentary inquiries brought interested and expert opinion, including departmental opinion, before MPs and a wider public. The inquiries acted as a 'forcing device' engaging stakeholders in a process of advocacy and (reciprocal) social learning. At the outset, different groups might have perceived themselves to be winners or losers 
or just interested parties. Through a process of public inquiry, all participants gained understanding about other perspectives and concerns and the opportunity thus opened up to develop more encompassing approaches.

The fact that Parliament was the setting for this process, that parliamentary opinion influenced the outcome and that votes on the floor of Parliament counted, was vital for its impact on interest groups, departments and ministers. Further, parliamentary inquiries on strategic issues, matters that were more or less outside the immediate partisan contest, required MPs to seek common ground and, where this proved elusive, at least to isolate points of difference. The whole process occurred in the public domain with evidence sessions published and available for scrutiny and review. Particularly on strategic issues, such inquiries provided opportunities for departmental officers to be cross-examined in public and departmental opinion to be disclosed.

In sum, in renewing the link between the Australian community and the formal policy-making system, there is only one institution in the political structure with the necessary formal standing and authority. This is the Parliament. It is the only institution capable of playing a pivotal or keystone role. It is the only institution capable of achieving an immediate, comprehensive and direct impact on interest-group and official opinion and through this development, broader public opinion. It provides the only institutional setting where the scope for explicit consensus between partisans can could be explored and expressed. Committees are the right institutions to introduce new strategic issues to the political agenda and to engage interest groups and the broader community in the consideration of these issues. This is for example, the role they can play in the United States Senate, the Chamber on which our own Senate was modelled. The House of Commons has also considerably strengthened its Select Committee system in recent years. Whilst not matching fully the 'contemplative' role envisaged here, enquires have become an important adjunct to official policy-making processes. Committee roles are far more developed than those of their counterparts in Australia.

The proposal I advocate would involve parliamentary arrangements specially focused on the long term. These would be outside the immediate direct authority of the government and the immediate influence of the major policy departments such as Treasury, Defence, and Prime Minister and Cabinet. This would be a virtue. Deliberation could occur without commitment of the government. Yet committees with standing in the policy development process would attract interest, media and public attention. They can provide a forum where official, novel, sectional and deviant or marginal opinions can be voiced. Bureaucrats, ministers, interest groups and independent experts can appear on an equal footing. Finally, through its varied processes and deliberations, Parliament can seed the formation of broader public opinion. The theatre of Parliament creates 
the cameo dramas that communicate the significance of issues to a broader public. This is now mainly fostered through rituals such as Question Time and Urgency Motions that have lost their original purpose. The political drama needs to be refashioned to contribute positively to the development of sectional and public opinion.

To amplify Parliament's standing in the broader political structure, its committees need to have enhanced roles and powers. The present parliamentary committee system is inappropriately structured; committees are insufficiently focused. The committee system would need to be reworked. The present committees work on a shoestring. The incentives for committee work are weak; those with ministerial ambitions may be fearful of taking an independent line. Finally, the use of latent parliamentary powers, particularly in the Senate, to gain attention for committee findings and recommendations is hugely underdeveloped.

Why might committees, working as routine participants in policy-making processes, make the contributions foreshadowed in this chapter? The theoretical base for these proposals can only be mentioned in passing. Recent scholarly work has accorded critically important roles to ideas. These are the foundation for policy adaptation and change. Institutional theory provides the relevant theoretical paradigm. One strand of institutional theory, historical institutionalism, focuses on continuities and a more recent branch, constructivist institutionalism, focuses on policy change and adaptation (e.g. Hay, 2006; Blyth, 2002; Crouch, 2005; D. Marsh et al, 1999). Some noted scholars might qualify this rough summary (e.g. Hall, 2007; Streeck and Thelen, 2005). These arguments continue. In a constructivist perspective however, ideas function as political solvents and catalysts in a number of specific ways. In a medium term perspective, ideas can mediate adaptive institutional development. Mark Blyth has enumerated the five ways that ideas facilitate this outcome (2002, pp. 36-40). First, in periods of crisis ideas reduce uncertainty. Second, following uncertainty reduction, ideas make collective action and coalition building possible. Third, in the struggle over existing institutions, ideas are weapons. Fourth, following the de-legitimation of existing institutions, new ideas act as institutional blueprints. Fifth, following institutional construction, ideas make institutional stability possible.

Elsewhere, and building on Lindblom's work on partisan mutual adjustment, I have discussed the ways ideas also facilitate more immediate accommodation between protagonists (1995, pp. 217-219). Agreement is of course one possibility, but in politics often a rare ground for accommodation. A second ground might involve issue redefinition as a concern is re-framed in more encompassing terms. Third, accommodation may be achieved through commitment to a later review to check that promised outcomes have been realised. Fourth, accommodation might be based on procedural acceptance - I do not agree with the result but 
I accept that the process is fair. Finally, consent might be elicited through compensation or log rolling. The formal political and policy-making system to provides the setting in which ideas perform these integrative tasks. The present Australian policy-making structure needs to be developed to allow ideas to do their work of accommodation and integration. They can mediate policy adaptation and change and - what is the same thing - they can create a better alignment between the social base of the policy-making system and the formal structure.

\section{Conclusion: is political change likely?}

In line with other commentators (notably Hay, 2006; Marquand, 2004), this paper has argued that the central political problem concerns the gap between the formal system and the people whom it purportedly represents. This is a systemic problem, the result of a failure to adapt the formal structure to profound change in its social base. It has been compounded by the primary basis for policy development post-1983: tacit bipartisanship. This top-down process facilitated rapid policy change with minimal attention to public consent. Meanwhile, in their (public) struggle for office, the major parties have adopted populist and opportunist approaches and they have manufactured or suppressed difference. Citizens may not know what is wrong, but they recognise that much of this political drama is a charade. They see that media events dominate political communications. They see that parliamentary rituals and debates are mostly irrelevant. They see that the major party organisations no longer exercise linkage and communication roles. Memberships are tiny. Conferences are wholly stage managed. These outcomes are a consequence of the incentive structure implicit in adversarial politics. Indeed, there is other evidence that Australian's engagement in politics is undiminished. Citizen energies are now channelled in unconventional activities - for example, the enormous success of the Get-Up organisation and its campaigns, the numbers who have participated in anti-war and pro-reconciliation activity, or the new role of Christian and pro-family organisations.

Yet at first blush, it may seem far fetched to anticipate amendment of the formal structure of politics and policy-making. After all, this architecture is firmly rooted in habits and expectations not just of elites but of the public more generally. Quite properly, the inertial forces are formidable. Change in the formal structure of power is rightly no casual development. As many recent democratic transitions illustrate, such developments are often associated with crisis, turbulence and physical force. Yet with the adoption of MMP New Zealand has recently initiated a peaceful formal change in the structure of power. Through changes in party strength and alignments in Parliament, Australia had a similar experience in 1909. A capacity for peaceful regime adaptation has, since the seventeenth century, made British politics exemplary for others (Beer, 1965). So, although rightly rare, such developments are not unheard of. Further, 
Australia's Constitution allows such possibilities. The structure of executive power is not constitutionally determined as for example in the case of the United States. It is rather based on three conventions - ministerial responsibility, confidence and collective cabinet responsibility. These conventions are determined by vote on the floor of Parliament, not by constitutional fiat.

Short of a referendum on the voting system (as occurred in New Zealand), there would seem to be at least two broad paths to structural amendment. One would involve a bottom up movement against the established parties. The other might involve executive action. An executive might recognise that its electoral vulnerability ultimately merits an effort to engage the community more effectively in policy development processes. These possibilities are reviewed in turn.

\section{New parties}

If minor party support grew sufficiently, the minor parties could take the initiative in proposing change. There are many ways in which they could negotiate with the government or the Opposition. Perhaps above all, they could trade a preference deal for the support of a major party in House of Representatives elections for a real change in the committee structure in the Senate. As I have argued elsewhere, the capacity of minor parties to show their supporters that they are not clones of the government that they are sustaining is critical (1990). Yet backdoor negotiations with the executive run this risk. My earlier study concerned the fate of the Liberals in the UK after the Steel-Callaghan pact was established in the 1970s. The Liberal leader, David Steel, was unable to convince his followers outside Parliament that he had advanced party interests whilst also sustaining the government. In Australia, the Democrats succumbed to analogous problems in their approach to the GST. The Australian Greens face the same difficulty if they become a balance of power party. Yet the experience of the Democrats is also salutary. They were only able to wield a balance of power when supported by one or other of the major parties. Stanley Bach has shown the extent to which in practice the two major parties vote together in the Senate, thus undercutting the influence of minor parties (2003). Adversarial rituals prevail in the House. Shared major party self-interest has mostly prevailed in the Senate.

In any case, to negotiate a deal with a major party as significant as that envisaged here, a minor party would need $t$ be able to demonstrate control of a tranche of votes far beyond that which the Democrats mustered in the past or the Greens do now. Finally, given the parlous state of the Liberal Party, a split along Free Trade and Protectionist lines cannot be ruled out. Electoral incentives are a powerful inertial force. But before its reconstitution by Sir Robert Menzies, splits were a regular feature. At this stage such a scenario is wholly speculative but perhaps also not to be wholly discounted. 


\section{Executive initiative}

At first blush it may seem unlikely that any executive would freely encourage the development of a new transparent phase in the policy-making process. After all this would be based on structures over which, at best, it would only have indirect influence. Yet the case studies of policy-making by the Howard Government pointed to the serious gaps in present arrangements, gaps which severely constrain the governments' political strategy, indeed bias it towards wedge, opportunist and populist tactics.

There are two reasons to believe structural change may not be wholly unacceptable to an enlightened/ambitious executive. One involves looking backward to the experience of the Howard governments. The other involves looking forward to the emerging policy agenda. Both major parties broadly agreed with the deregulatory and liberalising agenda introduced by Labor in 1983 and continued by the Howard governments from 1996. This micro-economic and deregulatory agenda has now just about run its course. It involved actions by government that liberalised market structures. Assessments were required at the level of the whole economy. Discriminatory or sectoral policies were disfavoured as was the engagement of affected interests. Indeed as public choice theory demonstrated, engagement of affected interests would more likely have corrupted the policy process. Thus the past received wisdom has been to discredit interest groups as selfish and self-serving and distance them as much as possible from policy-making processes.

Emerging policy issues are wholly different in character. Let us take just three: innovation and the knowledge economy; the environment and climate change; and public services such as health, education, hospitals and welfare. In relation to innovation, whilst unfettered markets are absolutely necessary in promoting this outcome, they are not sufficient. The knowledge system that surrounds any particular sector or region is no less important than the market structure in driving continuous improvement. This is the essential conclusion of innovation theory (e.g. West, 2006; Lipsey, Carlaw and Bekar, 2005). This introduces considerations quite other than those pertinent to the deregulating and liberalising agenda that has dominated in the past two decades. Now capacities to mobilise interests and to engage them at sectoral levels become much more critical. Capacities for analysis at sectional and regional levels are also required. In passing, we might note that a strategy based around innovation and the knowledge economy would, if fully developed, be tantamount to the renewal (in another key) of Deakin's protectionist-arbitration strategy. This is because it would unite the most basic social and economic strategies. Access to life long learning would require new educational arrangements matched by support over periods of reskilling. General social security arrangements would need to be consistent with these developments. Meanwhile, federal and state economic 
strategies would be designed to encourage innovation and continuous improvement at sectoral and regional levels and to aid global engagement. A similar unification was the keystone of the 'Australian settlement' and the crowning achievement of social liberalism. In passing, we might also note that the argument developed in this paper in effect applies innovation theory to the national policy system. This foundational knowledge infrastructure also needs to be mapped and developed.

Climate change introduces an even greater imperative for interest and community mobilisation. If the scientific prognosis is only half right, the politics of adaptation promises to be fraught. The need to build deep understanding of implications and options is surely clear. It is equally clear that this process has barely begun. What infrastructure will underwrite these processes? We have clear evidence of deficient capacity in present arrangements. What else is possible? Finally, in relation to health and community services, federal-state relations are primarily involved. But even here, the COAG structure mobilises affected elites. Even in a developed form, it is unlikely to provide sustained access to broader public opinion or affected interests.

A strengthened parliamentary committee system is not of course a panacea for all issues of policy-making. A host of specialist and sectoral research, enquiry and mobilisation mechanisms will doubtless be required. These can augment the technical and mobilising capacities of the policy-making system. But none can match the parliamentary theatre in terms of formal standing and ability to engage interest groups, media and public attention. In an augmented architecture of policy-making, a reconfigured parliamentary committee system, focussed on the Senate, and drawing on the latent powers of that Chamber, offers the best capstone. Such a structure would introduce a contemplative phase to policy development. To avoid the fate of the Howard Government, moves down this path are clearly in the interest of an ambitious executive. Will it be willing to learn from the experience of its predecessors? Will it be sufficiently prudent to recognise its best interests?

\section{References}

Aitkin, D. 1977. Stability and Change in Australian Politics. Canberra: Australian National University Press.

Argy, F. 2007. 'Government advertising on industrial relations', Democratic Audit of Australia. Canberra: Australian National University.

Bach, S. 2003. Platypus and Parliament: The Australian Senate in theory and Practice. Canberra: Dept. of the Senate.

Beer, S. 1965. British Politics in the Collectivist Age, New York: Vintage Books. 
Blyth, M. 2002. Great Transformations: Economic Ideas and Institutional Change in the Twentieth Century. New York, Cambridge University Press.

Blyth, M. and R. Katz. 2005. 'From Catch-all Politics to Centralisation: The political economy of the cartel party.' West European Politics, 28(1): 33-60.

Braithwaite, J. and P. Drahos, 2000. Global Business Regulation. Melbourne: Cambridge University Press.

Brett, J. 2003. Australian Liberals and the moral middle class: from Alfred Deakin to John Howard. Cambridge: Cambridge University Press.

Crouch, C. 2005. Capitalist diversity and change: Recombinant governance and institutional entrepreneurs. Oxford: Oxford University Press.

Dalton, R. 2004. Democratic challenges, democratic choices: The erosion of political support in advanced industrial democracies. Oxford: Oxford University Press.

Dryzek, J. 2000. Deliberative democracy and beyond: liberals, critics and contestations. Oxford: Oxford University Press.

Gollan, R. 1960. Radical and working class politics: A study of Eastern Australia, 1850-1910. Melbourne: Melbourne University Press.

Hall, P. 2007. The Evolution of Varieties of Capitalism in Europe. Minda de Gunzburg Centre for European Studies, Harvard University.

Hamilton, C. 2007. Scorcher: The Dirty Politics of Climate Change. Melbourne: Black Inc. Agenda.

Hay, C. 2006. 'Constructivist institutionalism', in The Oxford Handbook of Political Institutions, R. Rhodes, S. Binder and B. Rockman (eds). Cambridge: Cambridge University Press.

Hay C. 2007. Why we hate politics. Cambridge: Polity Press.

Henry, K. 2007. Address to the International Project Managers Symposium, Canberra, 9 February.

Keating, M. 2004. Who Rules: How Government Retains Control of a Privatised Economy. Sydney: Federation Press.

Lindblom, 1965. The Intelligence of Democracy: Decisionmaking through Mutual Adjustment. New York: The Free Press.

Lipsey, R., K. Carlaw, and C. Bekar. 2005. Economic transformaions: General purpose technologies and long term economic growth. Oxford: Oxford University Press.

Lloyd, J. 2004. What the media are doping to our politics? London: Constable. 
Mair, P. 1997. Party system change: Approaches and interpretations. Oxford: Clarendon Press.

Marquand, D. 2004. Decline of the Public: The Hollowing-out of Citizenship. Cambridge: Polity Press.

Marsh, D., J. Buller, C. Hay, J. Johnston, P. Kerr, S. McAnulla and M. Watson. 1999. Postwar British Politics in Perspective. Cambridge: Polity Press.

Marsh, I. and D. Yencken. 2005. Into the Future: The Neglect of the Long Term in Australian Politics, Melbourne: Black Inc.

Marsh I. 1985. Policy-making in a Three Party System, London: Methuen.

— 1990. 'Liberal Priorities, the Lib-Lab Pact and the Requirements for Policy Influence.' Parliamentary Affairs 43(3): 292-321.

— 1995. Beyond the Two Party System. Melbourne: Cambridge University Press.

- 2006. 'Neo-liberalism and the decline of democratic governance in Australia: A problem of Institutional Design?' Political Studies, 53, 1, pp. 22-43.

— 2006 b (ed.) Political parties in Transition? Sydney: Federation Press.

- 2007. 'Political institutions and the corruption of political opinion.' Australian Journal of Public Administration 66(3): 329-341.

McAdam, D., J. McCarthy and M. Zald (eds). 1996. Comparative Perspectives on Social Movements: Political opportunities, mobilizing structures and cultural framings. Cambridge: Cambridge University Press.

McKenzie, R. 1958. 'Parties, Pressure Groups and the British Political Proces', The Political Quarterly 29 (1) , 5-16.

Mills, S. 1986. The New Machine Men: Polls and Persuasion in Australian Politics. Ringwood: Penguin Books.

Pettit, P. 1997. Republicanism: A theory of freedom and government. Oxford: Clarendon Press.

Stoker, G. 2006. Why Politics Matters, Making Democracy Work. Basingstoke: Palgrave Macmillan.

Streeck, W. and K. Thelen (eds) 2005. Beyond Continuity: Institutional change in advanced political Economies. New York: Oxford University Press.

West, J. 2006. An Economic Strategy for NSW. Hobart: Australian Innovation Research Centre.

Wooden, M. 2007. 'Wage pressure danger lurks on both roads', On Line Opinion. URL: <www.onlineopinion.com.au/view.asp?article $=6607>$. Accessed November 2007. 


\title{
Yankelovitch, D. 1992. Coming to Public Judgement. New York: Syracuse University Press.
}

\author{
Zaller, J. 1992. The Nature and Origins of Mass Opinion. Cambridge: Cambridge \\ University Press.
}

\section{ENDNOTES}

1 'Bring David Hicks Home'. Accessed 19 February, 2008, at http://www.getup.org.au/ campaign/BringDavidHicksHome

2 This is not to overlook what has proved the most powerful source of policy change in the past two or three decades, namely tacit bipartisanship. The major parties tacitly accepted all the major policy changes proposed after 1983 save for the GST and Telstra privatisation. Both of these measures were subsequently introduced by the Howard governments.

3 Oliver MacDonagh describes analogous dynamics in his account of policy-making processes in the nineteenth century in the UK, before the development of mass parties: 'After 1820 ... Select Committees were used with a regularity and purpose quite without precedent. It is difficult to overestimate the importance of this development. Through session after session, through hundreds of inquiries and the examination of many thousands of witnesses a vast mass of information and statistics was being assembled. Even where (as was uncommonly the case) the official enquiry was in the hands of unscrupulous partisans, a sort of informal adversary system usually led to the enlargement of true knowledge in the end. A session or two later the counter-partisans would secure a counter exposition of their own. All this enabled the administration to act with a confidence, a perspective and a breadth of vision which had never hitherto existed. It had also a profound secular effect on public opinion generally and upon parliamentary public opinion in particular. For the exposure of the actual state of things in particular fields was in the ling run probably the most fruitful source of reform in nineteenth century England.' Oliver MacDonagh, Early Victorian Government, 1830-1870, Holmes and Meir, New York, 1977, p. 6. 